Bartłomiej Majchrowicz

Uniwersytet Śląski w Katowicach/Muzeum w Chorzowie e-mail: bbbmajchrowicz@gmail.com

ORCID: 0000-0003-2646-2193

DOI: 10.15290/mhi.2021.20.01.05

\title{
Prawo czy bezprawie? O legalności wprowadzenia Niemieckiej Listy Narodowościowej na Górnym Śląsku w świetle czwartej konwencji haskiej postrzeganej przez pryzmat wykładni prawa międzynarodowego przez prawników niemieckich i polskich
}

\begin{abstract}
ABSTRAKT
W poniższym artykule postaram się przedstawić sprawę Niemieckiej Listy Narodowościowej na Górnym Śląsku widzianą z trzech perspektyw historycznoprawnych razem z krótkim omówieniem jak wpłynęła ona na los Górnoślązaków oraz kształtujące się w jej świetle relacje polsko-niemieckie. Po krótkim opisie najważniejszych skutków wprowadzenia Niemieckiej Listy Narodowościowej na Górnym Śląsku oraz jej wpływu na relacje ludności polskiej i niemieckiej przejdę do opisu pierwszej części historycznoprawnej, w której zaprezentuję literalne brzmienie czwartej konwencji haskiej (ze szczególnym uwzględnieniem działu trzeciego traktującego o wykonywaniu okupacji) wraz z przykładem jej zastosowania po I wojnie światowej. W kolejnej części przedstawię polską wykładnię jej postanowień w kontekście oceny legalności wprowadzenia Niemieckiej Listy Narodowościowej na Górnym Śląsku. W ostatniej części przedstawię odmienne stanowisko prawników niemieckich, aby możliwe stało się osiągnięcie mojego głównego celu badawczego, jakim było przedstawienie (w sposób porównawczy) jak ważną rolę w prawie międzynarodowym odgrywa jego wykładnia - chociaż teksty konwencji są najczęściej formułowane w jasny sposób i po pierwszym zetknięciu się z ich brzmieniem nie budzą w interpretatorze wątpliwości, to mimo wszystko stwarzają możliwość
\end{abstract}


szerokiej, często jawnie godzącej w fundamenty całego porządku międzynarodowego wykładni. Choć sam przykład jest historyczny, tematyka różnic w wykładni prawa międzynarodowego jest w dzisiejszych czasach, przy postępującej globalizacji oraz integracji międzynarodowej, szczególnie ważna. W artykule wykorzystane zostały zarówno teksty aktów prawnych ( czwartej konwencji haskiej i paktu Brianda-Kellogga), jak i ich późniejsze interpretacje przez prawników polskich oraz niemieckich.

\section{ABSTRACT \\ Law or Lawlessness? The Legality of Introducing the German People's List in Upper Silesia in the Light of the Fourth Hague Convention Perceived by the Interpretation of International Law by German and Polish Lawyers}

In the following article, I will attempt to present the matter of the German Nationality List in Upper Silesia from three historical and legal perspectives, as well as a brief overview of how it influenced the fate of the Upper Silesians and the Polish-German relations. After a short description of the most important results of the introduction of the German Nationality List in Upper Silesia and its impact on the relations between the Polish and German people, I will present the literal wording of the Fourth Hague Convention (with particular emphasis on the third chapter including the exercise of occupation) and show an example of its use after the First World War. In the next part, I will present the Polish legal interpretation of its provisions in the context of assessing the legality of introducing the German Nationality List in Upper Silesia. In the last part, I will present the different standpoint of German lawyers to achieve my main research goal, which was to present (in a comparative way) the importance of the legal interpretation in international law - although texts of the conventions are most often formulated clearly and initially their wording does not raise any doubts in the interpreter, they create the possibility of a broad interpretation, often openly undermining the foundations of the entire international order. Although the example itself is historical, the subject of differences in the interpretation of international law is particularly important nowadays, with the advancing globalization and international integration. The article uses both the texts of legal acts (the Fourth Hague Convention and the Briand-Kellogg Pact) and their subsequent interpretations by Polish and German lawyers. In the part concerning Polish-German relations in the light of the German Nationality List in Upper Silesia, the memories of witnesses of history were also used.

Słowa kluczowe: prawo, historia, historia prawa, stosunki polsko-niemieckie

Key words: history, law, history of law, Polish-German relations 


\section{Słowo wstępne}

Niemiecka Lista Narodowościowa była głównym narzędziem niemieckiej polityki narodowościowej prowadzonej na Górnym Śląsku w latach 1939-1945. Spór o legalność jej wprowadzenia w świetle prawa międzynarodowego toczono między prawnikami polskimi i niemieckimi przede wszystkim w kontekście procesu norymberskiego oraz późniejszej historiografii głównie na podstawie literalnego znaczenia czwartej konwencji haskiej. Jednak dotychczas nie próbowano podjąć próby spojrzenia na tę problematykę z perspektywy nie tyle sporu o interpretacje konkretnego aktu prawnego czy też określenia stanu faktycznego związanego ze stosowaniem postanowień konwencji, lecz przez pryzmat odmiennych wzorców wykładni całego prawa międzynarodowego, które w rezultacie prowadzą do różnego rozumienia używanych znaczeń oraz oceny ich wagi. Niezależnie natomiast od prawnych aspektów związanych z wprowadzeniem w życie Niemieckiej Listy Narodowościowej na Górnym Śląsku najważniejszą konsekwencją jej wprowadzenia było faktyczne powiązanie obywateli polskich ze strukturami państwowymi III Rzeszy oraz włączenie ich w poczet niemieckiej wspólnoty narodowej (Volksgemeinschaft). W poniższym artykule postaram się przedstawić zarówno bardziej teoretyczny aspekt związany z możliwością odmiennej interpretacji co do dopuszczalności i legalności wprowadzenia Niemieckiej Listy Narodowościowej w świetle tego samego aktu prawa międzynarodowego, jaki stanowi czwarta konwencja haska, jak również faktyczne konsekwencje jej wprowadzenia dla relacji polsko-niemieckich.

\section{Geneza wprowadzenia Niemieckiej Listy Narodowościowej na Górnym Śląsku oraz jej wpływ na kształtowanie się stosunków między ludnością polską i niemiecką}

Niemiecka Lista Narodowościowa na Górnym Śląsku została wprowadzona rozporządzeniem z dnia 4 marca 1941 r., uzupełnionym następnie przez rozporządzenie z 31 stycznia 1942 r. U podłoża decyzji o jej wprowadzeniu legła przede wszystkim przegrana przez Wojsko Polskie kampania wrześniowa. Po krótkim okresie wojskowej administracji, Górny Śląsk (wraz z innymi Ziemiami Zachodnimi RP) został na mocy $\$ 4$ dekretu o podziale i zarządzie wschodnich obszarów z 8 października 1939 r. wcielony do Rzeszy Niemieckiej ${ }^{1}$. Pozwoliło to na wprowadzenie szczegółowych rozporządzeń, które miały ukształtować nowe stosunki narodowościowe na Górnym Śląsku. Ostatecznie w swoich założeniach dzieliła ona ludność autochtoniczną na cztery grupy:

1 A. Konieczny, Pod rządami wojennego prawa karnego Trzeciej Rzeszy Górny Śląsk 1939-1945, Wrocław-Warszawa 1972, s. 103. 
I. Osoby narodowości niemieckiej wykazujące przed 1 września 1939 r. aktywność na rzecz niemczyzny.

II. Osoby narodowości niemieckiej bierne w walce narodowościowej.

III. Wewnątrz grupy trzeciej możliwe jest rozróżnienie trzech podgrup:

a) Osoby pochodzenia niemieckiego, które $z$ biegiem czasu uległy polonizacji, jednak ze względu na ich postawę można było przypuszczać, że będą pełnowartościowymi członkami wspólnoty narodowej.

b) Osoby nieniemieckiego pochodzenia, żyjące w małżeństwie z osobami narodowości niemieckiej.

c) Osoby o niewyjaśnionej przynależności narodowej, które przed 1 września 1939 r. nie przyznawały się do niemczyzny i posługiwały się językiem słowiańskim.

IV. Osoby pochodzenia niemieckiego, całkowicie spolonizowane, tzw. renegaci.

Każda z grup otrzymała własny rodzaj dowodu osobistego - w przypadku dwóch pierwszych grup były to dokumenty w kolorze niebieskim, grupie trzeciej wydawano dokumenty w kolorze zielonym, a w przypadku grupy czwartej czerwonym $^{2}$. Najważniejsze były jednak skutki prawne związane z przynależnością do jednej ze wskazanych grup - grupy I i II otrzymywały niemiecką przynależność państwową ze skutkiem od 26 października 1939 r. natomiast wpisani do grupy III otrzymywali przynależność państwową z możliwością odwołania (w okresie 10 lat od daty przyjęcia Volkslisty) ${ }^{3}$. W przypadku grupy IV możliwe było uzyskanie przynależności państwowej do odwołania, jednak tylko poprzez nadanie obywatelstwa (czyli fakultatywnie) ${ }^{4}$.

$\mathrm{O}$ ile pierwsze dwie grupy pokrywały się w zasadzie z przedwojenną mniejszością niemiecką, o tyle grupę III i IV tworzyła ludność legitymująca się przed wybuchem wojny obywatelstwem polskim, niewchodząca w skład niemieckiej mniejszości narodowej. Najszersza oraz najbardziej zróżnicowana była grupa III. To właśnie do niej przypisano zdecydowaną większość Górnoślązaków. Chociaż początkowo przynależność do tej grupy nadawano wyłącznie w drodze nadań jednostkowych od 16 lutego 1942 r. rozpoczął się proces jej masowego nadawania (za sprawą wprowadzenia przymusu składania wniosków o wpisanie na DVL. Raz złożone oświadczenie woli nie mogło być później odwołane) ${ }^{5}$. Według danych z 10 października 1943 r. liczba zapisanych na DVL wyniosła

2 L. Olejnik, Zdrajcy narodu? Losy Volksdeutschów w Polsce po II wojnie światowej, Warszawa 2006, s. 26.

3 Ibidem, s. 27.

4 Ibidem.

5 Ibidem, s. 31. 
na Górnym Śląsku 1,29 mln osób, z czego do grupy III przyporządkowano $73 \%$ wszystkich zapisanych ${ }^{6}$.

Na skutek nadania polskiej ludności Górnego Śląska obywatelstwa niemieckiego doszło do jej prawnego oraz faktycznego połączenia z Niemiecką Wspólnotą Narodową (Volksgemeinschaft). Konsekwencje takiego prawnego powiązania dla wzajemnych relacji polsko-niemieckich były widoczne na każdym kroku codziennej egzystencji.

Przede wszystkim należy podkreślić, że Polacy przyporządkowani do III grupy DVL nigdy nie byli traktowani jako jej pełnoprawni członkowie. Oprócz szeregu praw i obowiązków, które faktycznie zbliżały posiadaczy III grupy DVL $\mathrm{z}$ resztą społeczeństwa niemieckiego (takimi jak: podleganie niemieckiemu prawu karnemu i cywilnemu, prawo do zawierania związków małżeńskich i adopcji dzieci w ramach niemieckiej wspólnoty narodowej, zachowanie prawa do posiadanego majątku i świadczeń socjalnych oraz przede wszystkim obowiązek służby wojskowej ${ }^{7}$ ) pozostawiono nadal liczne zakazy charakterystyczne tylko dla przedstawicieli tej grupy. Składały się na nie: brak możliwości otrzymania stanowiska dożywotniego urzędnika $\mathrm{w}$ administracji państwowej, stanowisk oficerskich w wojsku, stanowisk kierowniczych w urzędach oraz funkcji wymagających szczególnego zaufania takich jak nauczyciel czy majster ${ }^{8}$. Możemy na tym przykładowym wyliczeniu szczególnych uprawnień i zakazów zauważyć, że chociaż faktycznie oddzielono status prawny osób wpisanych do III grupy DVL od osób z grupy IV lub Polaków, którzy w ogóle nie zostali na nią wpisani, to jednak w dalszym ciągu "trójkowicze" nie byli traktowani jako pełnoprawni obywatele niemieccy. Prowadziło to do licznych napięć w relacjach pomiędzy polską ludnością wpisaną na DVL a resztą społeczeństwa niemieckiego na czele z organami władzy. Jaskrawy przykład możemy wynotować na gruncie prawa pracy - chociaż formalnie w $1941 \mathrm{r}$. na obszar wszystkich ziem wcielonych rozciągnięto niemieckie prawo pracy, jego postanowienia ograniczono wyłącznie do osób zakwalifikowanych do trzech pierwszych grup $\mathrm{DVL}^{9}$. W miejsce dotychczasowego prawa do pracy wprowadzono przymus pracy, co skutkowało znaczącym rozwarstwieniem wynagrodzeń finansowych. Z jednej strony jawnie dyskryminowano kobiety, bowiem nawet w okresie tzw. wojny totalnej, kiedy masowo zatrudniano je $\mathrm{w}$ przemyśle ciężkim, ich wynagrodzenie sięgało średnio zaledwie 23,66 marki tygodniowo (dla pracownic niewykwalifikowanych), podczas gdy odpowiednio (niewykwalifikowanym) pracownikom męskim płacono średnio 37,77 marki tygodniowo ${ }^{10}$. $\mathrm{Z}$ drugiej natomiast, dyskryminacja

\footnotetext{
Ibidem.

R. Kaczmarek, Polacy w Wehrmachcie, Kraków 2010, s.71.

Ibidem, s. 72.

9 R. Kaczmarek, Górny Ślask podczas II wojny światowej, Katowice 2006 s. 312-313.

10 Ibidem, s. 317.
} 
w polityce płacowej na Górnym Śląsku dotyczyła przede wszystkim pochodzenia narodowego robotników: np. w przemyśle węglowym średnie pensje sięgały raptem 74,4-76,6\% wynagrodzenia robotników wykwalifikowanych w głębi Rzeszy, podczas gdy na ternach wcielonych Górnego Śląska spadały one jeszcze niżej do wysokości około 69,8-72,4\% wynagrodzenia robotników wykwalifikowanych w głębi Rzeszy ${ }^{11}$. Ponadto osoby zaliczone do IV grupy DVL oraz Polacy, którzy nie zostali na nią wpisani, zostali obciążeni specjalnymi podatkiem tzw. daniną Polaków (Polenangabe) oraz społeczną daniną wyrównawczą (Sozialausgleichabgabe $)^{12}$. Pogłębiało to poczucie skonfliktowania Górnoślązaków z jednej strony ze znajdującymi się w gorszej sytuacji Polakami niewpisanymi na DVL lub uplasowanymi $\mathrm{w}$ jej najniższej grupie, $\mathrm{z}$ drugiej natomiast ze znajdującymi się w zdecydowanie lepszej sytuacji Niemcami. Najgłośniejsze jednak sprawy dotyczyły niespójnych podziałów w ramach rodzin. Znana jest np. sprawa skargi do Zentralstelle der DVL nauczyciela Maksa B., którego rodzicom nadano IV grupę DVL (pomimo faktu, iż ojciec powoda przed wojną był czynnym członkiem niemieckiej organizacji Volksbund), podczas gdy on sam oraz jego brat zostali przyporządkowani do grupy III. Następnie zostali oni powołani do Wehrmachtu oraz odznaczeni za postawę w działaniach wojennych, co miało skutkować przeniesieniem go do wyższej grupy DVL - co ciekawe, pomimo zasług syna dla wojska skargę oddalono, a rodziców nadal pozostawiono w grupie IV (czyli pomimo iż obaj synowie ryzykowali życie dla niemieckiej wspólnoty narodowej, ich najbliższa rodzina była obciążona specjalnymi opłatami oraz musiała liczyć się z groźbą wywłaszczenia) - podobne sytuacje wielokrotnie wpływały negatywnie na relacje polsko-niemieckie na Górnym Śląsku ${ }^{13}$. Spraw tego rodzaju było zdecydowanie więcej, a najgłośniejsze dotyczyły przypadków, w których mimo czynnej służby syna w wojsku niemieckim rodziców zdążono wywłaszczyć, a często również przesiedlić, jednak bez wątpienia do największych napięć na gruncie relacji polsko-niemieckich wynikających ze wpisu na DVL dochodziło w związku z odbywaniem służby wojskowej. Do niemieckiej terminologii wojskowej przeniknęło nawet słowo „Kaczmarek”, które pierwotnie (od czasów wojny prusko-francuskiej z lat 1870-1871) miało się odnosić właśnie do Polaków (i dotyczyło głównie Wielkopolan) odbywających służbę $\mathrm{w}$ armii niemieckiej. Później terminem tym zaczęto określać również nowo przybyłych, nieobytych jeszcze w walce żołnierzy. Postawy Ślązaków, którzy trafili do wojska niemieckiego były skrajnie różne - od otwartego oporu oraz dezercji przy pierwszej sposobności, przez bierne wykonywanie rozkazów oraz względne dostosowanie się do zaistniałej sytuacji aż do otwartej kolaboracji - jednak nawet $\mathrm{w}$ tym ostatnim przypadku nigdy nie udało się na stałe zahamować tarć

11 Ibidem.

12 Ibidem, s. 318.

13 R. Kaczmarek, Polacy w Wehrmachcie, s. 74. 
pomiędzy Górnoślązakami a resztą niemieckiej wspólnoty narodowej. Znamienną historię stanowi przypadek Alfonsa Białeckiego. Przed wojną uczęszczał on do polskiego gimnazjum w Katowicach, później do lokalnej szkoły górniczej ${ }^{14}$. W 1940 r. został powołany do Wehrmachtu i w trakcie swojej służby warunkowo (jako osoba wpisana na DVL) otrzymał stopień podporucznika oraz jedno $\mathrm{z}$ najwyższych odznaczeń niemieckich - krzyż rycerski ${ }^{15}$. Białecki swoją służbę traktował jako... młodzieńczą przygodę, dlatego ochotniczo zgłosił się do prestiżowych oddziałów spadochronowych ${ }^{16}$. Dobitnym dowodem, że po stronie Białeckiego nie wystąpiło ideologiczne zaangażowanie lub kolaboracja stanowi przypadek odnotowany podczas jednego z jego urlopów w rodzinnej miejscowości: po mszy świętej podszedł do grupy swoich polskich przyjaciół, z którymi rozpoczął prowadzenie rozmowy $\mathrm{w}$ gwarze górnośląskiej - w tym momencie podszedł do niego urzędnik państwowy zwracając uwagę, iż nie powinien (jako bohater wojenny) posługiwać się językiem polskim $\mathrm{w}$ miejscu publicznym ${ }^{17}$. W tym momencie Białecki uderzył urzędnika w twarz wykrzykując: „Das ist meine Muttersprache!”. Ponadto skutecznie interweniował w sprawie zwolnienia sąsiadów umieszczonych w KL Auschwit ${ }^{18}$. Na podstawie wspomnień innego uczestnika podobnych wydarzeń - Józefa Niesyto mogę przytoczyć historię niezwykle odmienną. Józef również został wcielony do Wehrmachtu, wcześniej odbywając jednak służbę przygotowawczą w Służbie Pracy Rzeszy (Reichsarbeitsdienst $)^{19}$. Podczas jej trwania był permanentnie ganiony za swoje polskie pochodzenie przez bezpośredniego zwierzchnika ${ }^{20}$. W czasie świąt Bożego Narodzenia musiał zostać na terenie koszar wspólnie z innymi, niższymi rangą powołanymi oraz przełożonymi. W wieczór wigilijny przełożeni szukali osoby, która potrafiła grać na akordeonie - padło na Józka, który odgrywał kolędy i inne skoczne melodie - od tego momentu jego stosunki z przełożonym uległy poprawie. Po wcieleniu do Wehrmachtu Józef został skierowany na front zachodni (na południu Francji) ${ }^{21}$. Mieszkańcy szybko zorientowali się, że zarówno Józef jak i kilku jego kolegów było w istocie Polakami. Zawarli nieformalną umowę, iż w dniu inwazji amerykańskiej zostaną ukryci przez lokalnego lekarza w jego mieszkaniu, w którym spokojnie doczekają wkroczenia wojsk alianckich ${ }^{22}$. Tak się jednak nie stało, ponieważ aliancka inwazja zastała Józefa w lazarecie poza linią frontu - dopiero w wyniku dalszych kolei losu Józefowi udało się oddać

14 Ibidem, s. 248.

15 Ibidem.

16 Ibidem.

17 Ibidem, s. 249.

18 Ibidem.

19 J. Niesyto, Kaj jest Józek? Wspomnienia wojenne Józefa Niesyto, Chorzów 2015, s. 57.

20 Ibidem

21 Ibidem, s. 58-60.

22 Ibidem, s. 63. 
w niewolę aliancką ${ }^{23}$. Zdecydował się on na wstąpienie do marynarki wojennej RP i po zakończeniu wojny powrócił do kraju. Jego brat (którego spotkał na wyspach) pozostał w Szkocji, gdzie założył rodzinę ${ }^{24}$.

Nie ulega wątpliwości, że na gruncie relacji polsko-niemieckich w związku z pełnieniem służby wojskowej zawsze panował rodzaj napięcia, które było widoczne przede wszystkim w sferze ich życia w „cywilu” np. w poziomie zróżnicowania płac, natomiast $\mathrm{w}$ momencie powołania do wojska relacje ulegały najczęściej zmianie. Bezpośrednio na froncie większość Polaków poczuwała się do konieczności wykonania obowiązku względem innych pobratymców, którzy trafiali razem $\mathrm{z}$ nimi do oddziałów, a $\mathrm{z}$ czasem również do frontowego koleżeństwa razem $\mathrm{z}$ Niemcami, które w niemieckim żargonie wojskowym określane jest jako Kameradenschft. Chociaż dla większości z nich droga do wyższych stopni kariery wojskowej była zamknięta, najczęściej nie odczuwali oni dyskryminacji na gruncie relacji z innymi towarzyszami broni. Problemem pozostawała sama konieczność służby w armii obcego państwa, którą postrzegano z jednej strony jako rodzinną tragedię (szczególnie w momencie skierowania na front wschodni), z drugiej natomiast za przymuszoną konieczność, bowiem rodziny osób, które odmawiały podjęcia obowiązku służby wojskowej, były narażone na ostre represje, łącznie z możliwością zesłania do obozu koncentracyjnego. Na froncie wschodnim większość Polaków w Wehrmachcie faktycznie podejmowała walkę z wojskami radzieckimi, ze strony których spodziewano się represji w przypadku dostania się do niewoli. Na froncie zachodnim większość Górnoślązaków starała się odnaleźć sposób na ucieczkę i zasilenie szeregów Polskich Sił Zbrojnych na Zachodzie (jak na załączonym przykładzie dwóch Górnoślązaków - Alfonsa Białeckiego i Józefa Niesyto). Na koniec warto zaznaczyć, że kształtowanie się relacji polsko-niemieckich w świetle Niemieckiej Listy Narodowościowej nie kończy się wraz z przywróceniem na terytorium Górnego Śląska polskiej jurysdykcji. Na skutek skomplikowanej sytuacji związanej z powojennymi zmianami granic oraz podjętej przez PRL próby rozliczenia się ze sprawą Volkslisty wielu Górnoślązaków zostało zmuszonych lub dobrowolnie wyjechało na terytorium kształtującego się powoli RFN. W 1970 r. po symbolicznej wizycie kanclerza Willy Brandta oraz normalizacji stosunków omiędzy Polską a RFN otworzyła się droga do tzw. programu łączenia rodzin, w wyniku którego doszło do kolejnych migracji ludności w obrębie obu państw w głównej mierze na gruncie indywidualnych sytuacji związanych ze sprawą Volkslisty - jest to już jednak temat na osobne studium.

23 Ibidem, s. 66-68.

24 Ibidem, s. 70-87. 


\section{Opis postanowień działu trzeciego czwartej konwencji haskiej oraz przykład ich zastosowania i wykładni po zakończeniu pierwszej wojny światowej}

Swoimi korzeniami konwencje haskie sięgają zorganizowanej w 1874 roku międzynarodowej konferencji brukselskiej, której uchwały doczekały się po ponad dwudziestu latach pierwszej kodyfikacji, uchwalonej na konferencji pokojowej w Hadze 29 lipca 1899 r. (chociaż ściśle rzecz ujmując kodyfikacja stanowi załącznik do konwencji i zawęża projekt uchwał brukselskich wyłącznie do wojny lądowej, a nie wojny jako zjawiska samego w sobie $)^{25}$. W kilka lat później podjęto następną kodyfikację „prawa wojny lądowej” (podjętą na drugiej konferencji pokojowej w Hadze 15 czerwca - 18 października 1907 r.) znaną jako załącznik do czwartej konwencji haskiej o prawach i zwyczajach wojny lądowej ${ }^{26}$. Regulowała ona nie tylko zasady prowadzenia wojny, lecz również sposoby przeprowadzenia okupacji i skutki jej zakończenia dla położenia ludności zamieszkującej tereny nią objęte. To właśnie postanowienia działu trzeciego (artykuły od 42. do 56.) konwencji traktującego o władzy wojennej na terytorium państwa nieprzyjacielskiego są kluczowe dla dalszej interpretacji działań podjętych przez władze niemieckie na Górnym Śląsku po 1939 r.

Okupacja zdefiniowana została jako stan faktyczny, którego przejaw stanowi faktyczne zajmowanie i kontrolowanie terytorium przez siły armii nieprzyjacielskiej - jednocześnie doprecyzowano, iż okupacja rozciąga się wyłącznie na te terytoria, gdzie władza okupanta została ustanowiona i może być faktycznie wykonywana (art. 42) ${ }^{27}$. Podstawowym zadaniem, które spoczywało na barkach okupanta w myśl postanowień konwencji było przywrócenie porządku i życia społecznego na podstawie (poza bezwzględnymi przeszkodami) przepisów prawa obowiązujących w okupowanym kraju (art. 43) ${ }^{28}$. W szczegółowy sposób wymieniono katalog zakazanych czynności, na który składały się:

1. Przymuszanie ludności okupowanego terytorium do udzielania informacji dotyczących armii przeciwnej lub strony wojującej (art. 44) ${ }^{29}$.

2. Przymuszanie ludności okupowanego terytorium do składania przysięgi wierności wobec państwa nieprzyjacielskiego (art. 45) ${ }^{30}$.

25 F. Ryszka, Norymberga. Prehistoria i ciag dalszy, Warszawa 1982, s. 46.

26 Ibidem.

27 Konwencja dotycząca praw i zwyczajów wojny lądowej (Dz.U. $1927 \mathrm{nr}$ 21, poz. 161), s. 20, http:// isap.sejm.gov.pl/isap.nsf/download.xsp/WDU19270210161/O/D19270161.pdf (21.02.2021).

28 Ibidem.

29 Ibidem.

30 Ibidem. 
3. Działanie przeciwko honorowi, prawu rodzinnemu, życiu jednostki, własności prywatnej (w tym konfiskaty) oraz zniesienia swobody wykonywania obrządków religijnych (art. 46) ${ }^{31}$.

4. Rabunek (art. 47) ${ }^{32}$.

5. Nakładanie na ludność terytorium okupowanego kar zbiorowych (w tym pieniężnych) za postępki jednostek w ramach odpowiedzialności solidarnej (art. 50) ${ }^{33}$.

6. Pobieranie kontrybucji $\mathrm{w}$ formie innej niż pisemnego rozkazu (i pod odpowiedzialnością naczelnego generała) oraz (w miarę możliwości) w zgodzie z przepisami opodatkowania i repartycji podatków obowiązujących. Za pobranie podatku należało wydać odpowiednie pokwitowanie $(\operatorname{art} .51)^{34}$.

7. Rekwizycje w naturze lub w ramach usług od gmin i mieszkańców dla podmiotów innych niż armia okupacyjna, przy czym zaznaczono, iż nie mogą one prowadzić do uczestnictwa ludności w działaniach wojennych przeciwko własnej ojczyźnie. Świadczenia w naturze powinny być w miarę możliwości opłacane w gotówce (art. 52) ${ }^{35}$.

8. Zajęcie, zniszczenie lub świadoma profanacja własności gmin, instytucji kościelnych, dobroczynnych, wychowawczych, sztuk pięknych, naukowych (która zawsze traktowana jest jako własność prywatna, nawet jeśli należy do państwa) oraz pomników historycznych, dzieł sztuki i nauki $(\operatorname{art} .56)^{36}$.

Na okupancie spoczywało również wiele obowiązków oraz mniejszy katalog uprawnień, które także poddano szczegółowemu wyliczeniu:

1. W przypadku pobierania na terytorium okupowanym ustanowionych na rzecz państwa podatków i opłat (w tym rogatkowych) powinno być to uczynione (w miarę możliwości) w zgodzie z obowiązującymi przepisami o opodatkowaniu i repartycji opłat, z czego wynika dla okupanta obowiązek pokrycia kosztów administracji danego terytorium w zakresie, $\mathrm{w}$ jakim był do tego zobowiązany rząd legalny (art. 48$)^{37}$.

2. Okupantowi przysługuje prawo do pobierania innych niż wymienione $\mathrm{w}$ art. 48 danin publicznych, o ile zostaną one przeznaczone na potrzeby armii lub administracji okupowanego terytorium (art. 49) ${ }^{38}$.

\footnotetext{
31 Ibidem.

32 Ibidem.

33 Ibidem, s. 21.

34 Ibidem.

35 Ibidem.

36 Ibidem, s. 22.

37 Ibidem, s. 21.

38 Ibidem.
} 
3. Okupantowi przysługuje prawo rekwizycji wyłącznie: gotówki, funduszy i papierów wartościowych, które stanowią własność państwa jak również składów broni, środków transportu, magazynów, zapasów zaprowiantowania oraz innego państwowego mienia ruchomego o ile może on służyć do celów wojennych. Wszelkie środki służące do przenoszenia wiadomości, osób i rzeczy ( $\mathrm{z}$ wyjątkiem środków regulowanych przez prawo morskie) jak również składy broni i amunicji mogą zostać zarekwirowane nawet jeżeli stanowią własność prywatną. Podlegają one zwrotowi $\left(\right.$ art. 53) ${ }^{39}$.

4. Kable podwodne łączące terytorium okupowane $\mathrm{z}$ terytorium neutralnym mogą być zarekwirowane i niszczone wyłącznie w wyniku bezwzględnej konieczności. Podlegają one zwrotowi (art. 54) ${ }^{40}$.

5. Okupant zobowiązany jest do ochrony wartości gmachów publicznych, nieruchomości, lasów i rolnych gospodarstw należących do państwa nieprzyjacielskiego, względem których uważać się będzie jedynie za administratora i użytkownika (art. 55) ${ }^{41}$.

Najbardziej znane zastosowanie konwencji przed 1945 r. związane jest z zakończeniem I wojny światowej. Tuż po podpisaniu aktu kapitulacji przez Niemcy została powołana specjalna komisja (tzw. komisja piętnastu) w celu zbadania odpowiedzialności sprawców wojny i ustalenia sankcji, jakie miały być przeciw nim orzeczone ${ }^{42}$. Najważniejszym osiągnięciem komisji na gruncie wykładni konwencji haskiej było sprecyzowanie katalogu 32 przypadków, które naruszyły prawa i zwyczaje wojny, w związku z czym powinny podlegać międzynarodowej jurysdykcji karnej (chociaż katalog opublikowano dopiero po zakończeniu II wojny światowej; wskazuje on jak kształtowała się wykładania przepisów konwencji w większości krajów europejskich) ${ }^{43}$. W'́ród nich znalazły się liczne stany faktyczne, z którymi zetkniemy się również w kontekście wprowadzenia Niemieckiej Listy Narodowościowej na Górnym Śląsku. Były to kolejno:

1. Deportacja osób cywilnych.

2. Uzurpowanie sobie suwerenności w warunkach okupacji militarnej.

3. Przymusowy pobór do wojska mieszkańców okupowanego terytorium.

4. Konfiskata własności.

5. Ściąganie bezprawnych i nadmiernie wysokich kontrybucji i rekwizycji. Chociaż wszystkie punkty wspomnianego katalogu zostały przyjęte jednogłośnie, nie znalazły się one w oficjalnej redakcji tekstu - stało się tak nie z powodu rozbieżności lub wątpliwości co do wykładni samej konwencji lecz

\footnotetext{
39 Ibidem.

40 Ibidem, s. 22.

41 Ibidem.

42 F. Ryszka, Norymberga..., s. 51.

43 Ibidem, s. 53.
} 
na skutek braku narzędzi umożliwiających usankcjonowanie odpowiedzialności karnej państwa i jego organów za złamanie jej postanowień (konwencja ustanowiła bowiem jedynie odpowiedzialność cywilną państw $)^{44}$. Z powyższego wynika, że samo stwierdzenie bezprawności (w kontekście postanowień konwencji) wymienionych działań nie było dyskutowane lecz zgodnie stwierdzone a jedyne rozbieżności i wątpliwości interpretacyjne były związane ze skutkami jakie powinno rodzić naruszenie jej postanowień, skoro nie zawierała ona przepisów dotyczących odpowiedzialności karnej państwa i jego organów.

\section{Czwarta konwencja haska i sprawa Niemieckiej Listy Narodowościowej w świetle wykładni prawa międzynarodowego wśród prawników polskich w latach 1918-1945}

Sprawa Niemieckiej Listy Narodowościowej na Górnym Śląsku doczekała się szerokiej gamy interpretacji ze strony prawników polskich, szczególnie po zakończeniu działań wojennych w maju 1945 r. w związku z mającym się rozpocząć procesem norymberskim. Jednak w swoich analizach wydanych tuż po zakończeniu II wojny światowej oddźwięk znajduje przede wszystkim przedwojenna wykładnia prawa międzynarodowego jak również samej konwencji, która ukształtowała wśród powojennych badaczy omawianej problematyki sposób postrzegania prawa.

Podstawowym zadaniem, przed którym stanęła polska doktryna prawna przed przystąpieniem do szczegółowego wymieniania pogwałceń postanowień czwartej konwencji haskiej w związku z wprowadzeniem Niemieckiej Listy Narodowościowej na Górnym Śląsku, było zdefiniowanie zjawiska okupacji. Powszechnie przyjęto, w pełnej zgodzie $\mathrm{z}$ literalnym brzmieniem konwencji, iż jest to stan przejściowy, bowiem ostatecznie kończy się albo na skutek usunięcia wojsk okupanta w związku $\mathrm{z}$ dalszymi działaniami wojennymi, albo przez zawarcie pokoju i przejście części terytorium jednego państwa w skład drugiego albo też przez zakończenie wojny drogą tzw. zawojowania (debellatio), które polega na całkowitym zniszczeniu państwa - podmiotu prawa narodów. Zatem okupant sprawuje nad przejętym terytorium władzę w imieniu własnym, jednak jedynie $\mathrm{w}$ zastępstwie wypartego państwa ${ }^{45}$. Powszechnie wiadomo, iż działania wojenne w 1939 r. nie zakończyły się podpisaniem porozumienia pokojowego bądź aktu kapitulacji. Powstaje zatem pytanie, czy działania, z których częściowym katalogiem czytelnik mógł zapoznać się w pierwszej części niniejszego artykułu, a które stanowiły w jawny sposób pogwałcenie przedstawionego

44 Ibidem, s. 50.

45 K.M. Pospieszalski, Pod niemieckim prawem 1939-1945 (ziemie zachodnie), Poznań, 1946, s. 203-204 . 
w części drugiej literalnego brzmienia przepisów konwencji dotyczących sposobu przeprowadzenia okupacji (przede wszystkim podejmowanie działań sprzecznych z obowiązującym na tych terenach do 1939 r. porządkiem prawnym) mogły znaleźć oparcie prawne w stanie faktycznym zawojowania państwa polskiego?

Karol Pospieszalski wskazuje na argumenty, które przemawiają na niekorzyść tezy głoszącej zawojowanie. Odwołując się do nauki niemieckiej wskazuje:

Samo zdobycie wrogiego terytorium państwowego nie wystarcza, by uzasadnić debellatio. (...) Stan faktyczny debellatio nie zachodzi już wtedy, gdy całe terytorium państwowe zostało zajęte. Trzeba nadto, by siły zbrojne państwa okupowanego zostały zniszczone, by rząd był w rozsypce, a władca w niewoli lub uciekł. Jeśli natomiast siły zbrojne państwa okupowanego kontynuuja walkę na terytorium sprzymierzeńca, a rząd sprawuje władzę z zagranicy, jak np. rząd belgijski podczas wojny światowej z Le Havre, nie zachodzi debellatio, a tym samym również nabycie suwerenności nad terytorium zajętym przez okupanta [podkr. - B.M.]. W takich przypadkach nadzieja na zmianę szczęścia wojennego nie jest wykluczona $^{46}$.

Uzupełnia ją definicja profesora Juliana Makowskiego, według której „debellatio stwarza prawo zwycięscy do terytorium państwa pokonanego dopiero wtedy, kiedy się okaże, że przyłączenie ma charakter stały (...) wobec czego poprzedni suweren nie ma możności odzyskania tego, co utracił"47. Przekładając zatem powyższe definicje na stan faktyczny, który zaistniał na ziemiach polskich po zakończeniu działań wojennych podczas kampanii wrześniowej możemy wykazać, że państwo polskie trwało nadal pomimo utraty kontroli nad całym jego obszarem. Francja oraz Wielka Brytania wypowiedziały wojnę Rzeszy Niemieckiej właśnie ze względu na niezaprzestanie prowadzonych przez nią działań wojennych przeciwko Polsce pomimo postawionego jej ultimatum. Z tego z kolei wynika, iż przywrócenie władzy polskiej na zajętym terytorium stało się podstawowym celem wojny ratując tym samym byt państwa polskiego. Na wagę takiego właśnie zestawienia państw walczących w bloku militarnym dla pojęcia debellatio zwraca uwagę Alfons Klafkowski cytując opinię profesora Ludwika Ericha z 1920 r., który zaznacza iż „szczególnie trudne jest stosowanie debellatio podczas wojny między grupami państw. W takim wypadku nawet całkowite zajęcie jednego państwa nie może oznaczać «debellatio», gdyż to państwo walczy na terytorium swoich sprzymierzeńców" 48 . Idąc jednak jeszcze głębiej w obowiązujące ówcześnie prawo narodów, możemy zauważyć, że na fakt powstania państwa jako podmiotu prawa narodów składają się dwa elementy: pojawienie

46 Ibidem, s. 208.

47 J. Makowski, Prawo międzynarodowe. Część I, Warszawa 1930, s. 303-304.

48 A. Klafkowski, Okupacja niemiecka w Polsce w świetle prawa narodów, Poznań 1946, s. 103. 
się nowego tworu, noszącego cechy państwa oraz uznanie go przez społeczność międzynarodową - zatem uznanie ma charakter konstytutywny dla powstania nowego podmiotu prawa międzynarodowego, jakim jest państwo i musi mieć swój odpowiednik również na gruncie zaniknięcia takiego podmiotu. Zatem do faktycznej utraty państwowości nie wystarczy jedynie utrata istotnych cech państwa - konieczne jest również uznanie tego faktu przez innych członków społeczności międzypaństwowej. W tym miejscu warto wspomnieć, iż instytucja uznania międzynarodowego również w jego współczesnym porządku stanowi podstawowe narzędzie rozstrzygające fakt powstania lub zaniknięcia państwa jako podmiotu prawa narodów.

Na koniec warto również wspomnieć, że doktryna polska była zgodna co do faktu, iż nawet w przypadku zawojowania stronę zwycięską obowiązywać miała legalna wykładnia skutków, jakie ów stan rodzi - profesor Julian Makowski słusznie zauważa, iż „ludność państwa podbitego nabywa via facti przynależność państwową zdobywcy i zlewa się z jego dotychczasową ludnością" ${ }^{9}$.

Po nakreśleniu uznawanej przez prawników polskich wykładni przepisów prawa międzynarodowego jak również samej konwencji haskiej wraz z zaprezentowaniem oceny stanu faktycznego związanego z okupacją terytorium państwa polskiego, która według nich nie zakończyła się w październiku 1939 r., lecz trwała aż do pełnego wyzwolenia kraju w 1945 r. możliwe staje się wykazanie licznych naruszeń postanowień działu trzeciego czwartej konwencji haskiej, których dopuścili się Niemcy wprowadzając Niemiecką Listę Narodowościową na terenie Górnego Śląska. W świetle przedstawionej interpretacji podstawowym naruszeniem było działanie władz okupacyjnych wbrew artykułowi 46 ., w świetle którego zabronione jest jakiekolwiek ograniczanie możliwości dalszego istnienia narodu zamieszkującego okupowane terytorium, tym bardziej poprzez działania, które mają na celu włączenie go w skład narodu okupującego teren. Czytelnik mógł już zaobserwować, iż jednym z podstawowych zadań stawianych przez niemieckie władze Niemieckiej Liście Narodowościowej było włączenie (szczególnie od 1942 r.) możliwie szerokiej grupy polskiej ludności Górnego Śląska w skład Niemieckiej Wspólnoty Narodowej za sprawą nadania jej obywatelstwa niemieckiego, co w jawny sposób pogwałca wspomniany artykuł. Tym samym naruszony został również art. 43 konwencji, który nakładał na okupanta obowiązek przywrócenia ładu na okupowanym terytorium w oparciu o lokalne przepisy prawne. $Z$ kolei konsekwencją naruszenia art. 46. Konwencji (za sprawą nadania części polskiej ludności Górnego Śląska obywatelstwa niemieckiego) było również naruszenie art. 45., poprzez przymuszenie jej do złożenia przysięgi na wierność państwu nieprzyjacielskiemu (za sprawą nałożenia

49 J. Makowski, op. cit., s. 277. 
na nią obowiązku służby wojskowej i związania z państwem niemieckim nie tylko z tytułu obywatelstwa, lecz również w związku z przysięgą wojskową).

Wymienione powyżej naruszenia przepisów konwencji stanowią jedynie zawężony katalog najważniejszych z nich, jednak, co ciekawe, w powojennej ocenie aspektów prawnych związanych z wprowadzeniem Niemieckiej Listy Narodowościowej na Górnym Śląsku główna uwaga polskich prawników skupia się na aspekcie bezprawności samej wojny, która doprowadziła do okupacji kraju. Zwracają oni uwagę, że zarówno Niemcy jak i Polska były stronami paktu Brianda-Kellogga, który stanowił iż „Wysokie Strony Umawiające się oświadczają uroczyście imieniem Swoich ludów, że potępiają uciekanie się do wojny celem załatwienia sporów międzynarodowych i wyrzekają się jej jako narzędzia polityki narodowej w ich wzajemnych stosunkach" ${ }^{50}$, a z tego wynika, iż zawojowanie mogłoby być wynikiem jedynie wojny legalnej, czyli przedsięwziętej (zgodnie z paktem Brianda-Kellogga) w celu samoobrony lub z ramienia społeczności międzypaństwowej. Warto w tym miejscu wspomnieć, że również Trybunał Norymberski przyjął podobną interpretację niemieckich działań w czasie wojny, wskazując w akcie oskarżenia w punkcie dotyczącym pogwałcenia traktatów międzynarodowych, iż

Statut Trybunału określa jako przestępstwo planowanie lub wszczęcie wojny napastniczej, bądź wojny naruszającej traktaty międzynarodowe. (...) Wobec tego jest rzeczą zbędną wchodzić w szczegóły sprawy, a nawet rozważać, w jakim stopniu te wojny napastnicze były również wojnami „z pogwałceniem międzynarodowych traktatów, gwarancji lub umów ${ }^{51}$.

Również w bezpośrednim odwołaniu do konwencji haskich podstawowym zarzutem wobec strony niemieckiej było pogwałcenie art. 1. trzeciej konwencji haskiej polegające na bezprawnym rozpoczęciu działań wojennych ${ }^{52}$. Z kolei w przypadku odwołania się do paktu Briana-Kellogga trybunał doprecyzował, że strona niemiecka zawarła (26 stycznia 1934 r.) z Polską opartą na wspomnianym akcie deklarację o utrzymaniu trwałego pokoju, która wykluczała użycie siły i obowiązywać miała przez 10 lat $^{53}$.

50 Traktat Przeciwwojenny, podpisany w Paryżu dnia 27 sierpnia 1928 r. (ratyfikowany zgodnie z ustawą z dnia 13 lutego 1929 r.) (Dz.U. $1929 \mathrm{nr}$ 63, poz. 489), s. 4, http://isap.sejm.gov.pl/isap.nsf/ download.xsp/WDU19290630489/O/D19290489.pdf (06.01.2021).

51 T. Cyprian, J. Sawicki, Walka o zasady norymberskie 1945-1955, Warszawa, 1956, s. 305.

52 Ibidem, s. 306.

53 Ibidem, s. 307. 


\section{Czwarta konwencja haska oraz Niemiecka Lista Narodowościowa w świetle wykładni prawa międzynarodowego w III Rzeszy}

Po przedstawieniu ogólnego opisu postanowień konwencji haskiej oraz zaprezentowania ich wykładni dokonanej po zakończeniu I wojny światowej jak również w okresie pomiędzy 1918 a 1945 r. (w środowisku prawników polskich) możliwe stało się zauważenie jak wiele $\mathrm{z}$ nich zostało naruszonych przez władze niemieckie w wyniku działań podjętych w ramach wprowadzania Niemieckiej Listy Narodowościowej na terenie Górnego Śląska. Analizując jednak powyższe działania nie należy pominąć zaprezentowania wykładni prawa międzynarodowego, na podstawie której były one podejmowane, szczególnie w kontekście obowiązywania lub też nieobowiązywania samej konwencji (w odczuciu prawników niemieckich z lat 1933-1945).

Podstawową zasadą ówczesnego prawa III Rzeszy, w świetle której należy postrzegać również wykładnię prawa międzynarodowego była zasada wodzostwa (Führerprinzip). Pierwszym z ówczesnych, niemieckich prawników, który starał się przedstawić jej wpływ na wykładnię prawa był Reinhard Höhn. W jego interpretacji powyższej zasady suwerenność nie pozostaje już atrybutem państwa jako osoby prawnej, w którego miejsce wstępuje Führer przewodzący i kierujący narodem dokonując tzw. Führung ${ }^{54}$. Sam naród jest wyłącznie prowadzony (geführt) i nie ma wpływu na przebieg całego procesu ${ }^{55}$. Zatem jedyna, suwerenna władza należy do Führera, który nie jest organem państwa, lecz znajduje się ponad nim ${ }^{56}$. W konsekwencji uznano, iż samo prawo (bowiem władza zaczyna się od stanowienia prawa) pochodzi zawsze od samego wodza i jest aktem jego woli ${ }^{57}$. W tym miejscu możemy już zauważyć, że cała koncepcja Führerprinzip sprowadzała się do utrzymywania prymatu prawa wewnętrznego nad prawem międzynarodowym. Już w tym kontekście należy postawić pytanie, czy w doktrynie prawnej III Rzeszy w ogóle istniało pojęcie prawa międzynarodowego - w istocie część teoretyków przeczyła jego występowaniu w ramach systemu prawnego III Rzeszy. W teorii Ernsta Wolgasta w miejscu dawnego „obiektywnego prawa międzynarodowego” istniały jedynie konkretne zobowiązania pomiędzy państwami, które opierały się na zasadzie pacta sunt servanda ${ }^{58}$. Z kolei Ludwig Scherer poszedł jeszcze dalej odrzucając istnienie osobnego prawa międzynarodowego na podstawie wykładni pojęcia wspólnoty, która dla Scherera może być jedynie wspólnotą narodową, dlatego wspólnota międzynarodowa nie istnieje, a tzw. prawo międzynarodowe jest wyłącznie ze-

54 F. Ryszka, Państwo stanu wyjątkowego. Rzecz o systemie państwa i prawa Trzeciej Rzeszy, WrocławWarszawa-Kraków-Gdańsk 1974, s. 243.

55 Ibidem.

56 Ibidem.

57 Ibidem, s. 245.

58 Ibidem, s. 252. 
wnętrznym prawem państwa ${ }^{59}$. Pomimo logicznej spójności między teoriami negującymi istnienie prawa międzynarodowego a samą Führerprinzip stanowiącą fundament całego systemu prawnego III Rzeszy przez cały okres jej istnienia konieczne było działanie i występowanie na arenie międzynarodowej (chociażby wyłącznie w celach wymiany handlowej). Okazuje się zatem, iż pomimo wewnętrznego odrzucenia i wyparcia norm prawa międzynarodowego z porządku prawnego III Rzeszy konieczne stało się opracowanie sposobu jego wykładni, która pozwoliłaby na stosowanie go w zgodzie i pod dyktando obowiązującego reżimu. W późniejszym okresie konieczne stało się również wykazanie, iż w wyniku kolejnych kampanii prowadzonych przez Wehrmacht oraz zajmowania coraz to nowych obszarów, na które rozciągała się niemiecka jurysdykcja i administracja nie doszło do jego pogwałcenia - oczywiście podobne cele zostały tej wykładni postawione w związku z gospodarowaniem byłymi obszarami II RP wcielonymi do Rzeszy w październiku 1939 r. W tym kontekście również działania przeprowadzone przez organy niemieckie na Górnym Śląsku w związku z wprowadzeniem Niemieckiej Listy Narodowościowej miały doczekać się silnej oraz logicznej (w odczuciu prawników niemieckich) podpory prawnej.

Największe znaczenie dla tak oportunistycznej wykładni prawa międzynarodowego miało wiele prac Carla Schmitta, z których bardzo ważne miejsce zajmuje jego wykład (wydany wraz z uzupełnieniami 28 lipca 1941 r. zatem już po wprowadzeniu Niemieckiej Listy Narodowościowej na Górnym Śląsku) pod tytułem Porzadek wielkoobszarowy w prawie międzynarodowym.

Podstawowym założeniem, na którym Carl Schmitt oparł swój wykład, jest postulat ustanowienia podmiotami prawa międzynarodowego (które według Schmitta jest jedynie prawem międzypaństwowym) tworów wielkoobszarowych, które zostają przez niego dookreślone jako rzesze ${ }^{60}$. W obrębie tak rozumianych podmiotów prawa międzynarodowego podstawę wszelkich relacji i zobowiązań stanowiłaby zasada nieingerencji sił trzecich w obrębie poszczególnych „rzesz"61.

Chociaż nie sposób odmówić Schmittowi słusznego zwrócenia uwagi na związane z postępem technologicznym zmiany w zakresie postrzegania przestrzeni (chociażby na gruncie obiegających nieustannie kulę ziemską fal radiowych lub statków powietrznych, które podczas jednego lotu przelatują przez obszary pozostające pod różną jurysdykcją) tak samo ciężko przychodzi możliwość oderwania takiego postulatu z kontekstu zaborczej polityki III Rzeszy. Ponadto sam autor zauważa:

59 Ibidem, s. 253.

60 C. Schmitt, Porządek wielkoobszarowy w prawie międzynarodowym, Warszawa 2009.

61 Ibidem. 
Niemiecko-rosyjski traktat o granicach i przyjaźni z 28 września 1939 roku (...) ustala granice „wzajemnych interesów państw [reich]” na terytorium byłego państwa polskiego. W art. 2 traktatu wyraźnie odrzuca się wszelką ingerencję sił trzecich w te ustalenia, a we wprowadzeniu podkreśla się, że traktat ma na celu zapewnienie żyjacej tam ludności pokojowego bytu odpowiadającego jej narodowej specyfice [sic!]. Tym samym system wersalski tak zwanej ochrony mniejszości w tej części Europy przestał istnieć" [pod. B.M. $]^{62}$.

Zatem według Schmitta, w ramach nowego porządku międzynarodowego, którego głównym propagatorem w owym okresie miała być III Rzesza, możliwe jest odrzucenie wszelkich, obowiązujących dotychczas przepisów prawa międzynarodowego, o ile stanie się to na skutek porozumienia między wielkoobszarowymi podmiotami (takimi jak Związek Radziecki i III Rzesza), bowiem prowadzi to do przekazania terytoriów zajmowanych dotychczas przez inne, mniejsze podmioty prawa międzynarodowego $\mathrm{w}$ sferę wewnętrznych regulacji umawiających się stron. Warto w tym miejscu zwrócić uwagę na wykładnię samego pojęcia Rzeszy zaproponowaną przez Schmitta:

Rzesza w tym sensie to przewodnia i nośna siła, której idea polityczna promieniuje na określony wielki obszar i która z zasady wyklucza interwencje obcych sił w tym obszarze. Wielki obszar nie jest oczywiście tożsamy z Rzeszą w tym sensie, iżby Rzesza była samym tym obszarem chronionym przez nią przed interwencjami; nie każde też państwo ani nie każdy naród z tego wielkiego obszaru same stanowią fragment Rzeszy, tak jak nikt uznający doktrynę Monroe nie będzie myślał o zaliczeniu Brazylii czy Argentyny do USA. Każda Rzesza wszakże ma pewien wielki obszar, w który wypromieniowuje swoją ideę polityczną i który nie może być terenem obcych interwencji ${ }^{63}$.

Powyższy cytat obrazuje dwa, bardzo ważne dla oceny wykładni prawa międzynarodowego w III Rzeszy zjawiska.

Pierwsze, stanowi obraz prymatu nie tylko prawa wewnętrznego nad międzynarodowym, lecz przede wszystkim dominację polityki nad prawem jako całością. Jest to wyraz bezpośredniego przełożenia doktryny wodzostwa na proces stanowienia i stosowania prawa. Zatem każda wola wodza, która pozostawała zjawiskiem politycznym mogła prowadzić do konkretnego oddziaływania na obszar pozostający fragmentem jej oddziaływania, które pozostawałoby wolne od zobowiązań prawa międzynarodowego.

Drugie, związane jest z koniecznością przedstawienia wykładni państwa jako podmiotu prawa międzynarodowego dokonanej przez Schmitta. Z cytowanego powyżej fragmentu wynika bowiem jakoby Schmitt nie odbierał pod-

62 Ibidem, s. 71-72.

63 Ibidem, s. 75. 
miotowości prawnej mniejszym i słabszym państwom, nawet jeśli zalicza je w orbitę oddziaływania III Rzeszy. Analizując jednak fragment dotyczący umowy niemiecko-radzieckiej korzysta on już z pojęcia „byłego państwa polskiego”. Co zatem decydowało według Schmitta o przetrwaniu państwa jako podmiotu prawa międzynarodowego?

Dzisiejsze współżycie różnych narodów, zwłaszcza dużych czy zagrożonych, wymaga właśnie sprawnej organizacji we właściwym sensie tego słowa, wymaga minimalnej miary wewnętrznej spójności i bezpiecznej obliczalności. Obejmuje też wysokie kwalifikacje duchowe i moralne, a dalece nie każdy naród jako taki dojrzał już do tego minimum organizacji i dyscypliny. Walka teorii prawa międzynarodowego z pojęciem państwa chybiałaby celu, gdyby nie uwzględniała poziomu rzetelnego porządku, jaki (...) był istotny dla dotychczasowego pojęcia państwa. Naród niezdolny do państwowości już w tym organizacyjnym tylko sensie nie może być podmiotem prawa międzynarodowego. Przykładowo wiosną 1936 roku okazało się, że Abisynia nie była państwem. Nie wszystkie narody potrafią zdać egzamin w postaci utworzenia dobrego nowoczesnego aparatu państwowego, a bardzo nieliczne stały się zdolne do prowadzenia nowoczesnej materialnej wojny mocą własnych organizacyjnych, przemysłowych i technicznych dokonań. Nowy porządek Ziemi, a tym samym zdolność do bycia dziś pierwszej rangi podmiotem prawa międzynarodowego wymaga wysokiego stopnia cech nie tylko „naturalnych” w sensie naturalnie z góry danych, lecz także świadomej dyscypliny, zaawansowanej organizacji i zdolności do utworzenia mocą własnych sił i do bezpiecznego utrzymania w swoich rękach aparatu nowoczesnej wspólnoty, który może powstać tylko dzięki poważnej koncentracji ludzkich interesów ${ }^{64}$.

Z powyższego cytatu wynika wiele bezpośrednich argumentów, w świetle których należy interpretować ówczesne postrzeganie przez niemieckich prawników systemu międzynarodowych zobowiązań oraz oceny podmiotowości międzynarodowej. Stanowi on również kontrwykładnię przepisów i zagadnienia obowiązywania konwencji haskiej względem wykładni dokonanej przez prawników polskich. Przede wszystkim obowiązywanie przepisów prawa międzynarodowego między państwami Schmitt wyprowadza nie z instytucji uznania, lecz z bliżej niedookreślonej zdolności do zorganizowania i utrzymania nowoczesnego aparatu państwowego. Podążając za przykładem podanym przez niego (Abisynia) należy uznać, iż taka wykładnia prowadzi również do legalizacji wojny napastniczej, bowiem jeżeli terytorium drugiej strony zostaje w pełni zajęte w wyniku działań zbrojnych, nawet jeżeli nie zostanie podpisane porozumienie pokojowe, a władza zwierzchnia uda się na emigrację za granicę, państwo przestaje nosić miano podmiotu prawa międzynarodowego, $\mathrm{z}$ takimi skutkami jak gdyby nigdy nim nie było. Przekładając powyższą wykładnię podmiotowości

64 Ibidem, s. 91-92. 
państwa na stan faktyczny związany z okupacją terenów II RP przez Niemcy od października 1939 r., możemy zauważyć, iż doktryna niemiecka prowadzi do całkowitego odebrania podmiotowości prawnej państwu polskiemu (skutki takiej interpretacji w wyniku zakończonej kampanii wojennej są zdecydowanie dalej idące niż potencjalne stwierdzenie zawojowania) - w tym kontekście przestały również (według prawników niemieckich) obowiązywać wszelkie postanowienia prawa międzynarodowego między Polską a Niemcami. Koronnym zwieńczeniem potwierdzenia słuszności tak dokonanej wykładni podmiotowości państwa miało być podpisanie dwustronnej umowy między Trzecią Rzeszą a Związkiem Radzieckim, która ustanawiała nowy porządek na tych terytoriach i wyłączała je spoza ingerencji państw trzecich ( $\mathrm{w}$ tym $\mathrm{z}$ postanowień prawa międzynarodowego). Podejmowany przez prawników polskich argument toczącej się nadal wojny koalicyjnej, która w sposób szczególny prowadziła do dalszego trwania państwa polskiego jako podmiotu prawa międzynarodowego doktryna niemiecka zbywa poprzez wskazanie konieczności posiadania zdolności do utrzymania wysokiego stopnia organizacji i prowadzenia nowoczesnej, materialnej wojny z wykorzystaniem własnych środków (zatem wyklucza możliwość trwania podmiotowości państwa w obliczu całkowitego zagarnięcia jego terytoriów, nawet jeśli jego rząd oraz siły zbrojne będą prowadziły w dalszym ciągu zmagania zbrojne z terytoriów państw sojuszniczych). W świetle tak przedstawionej wykładni podmiotowości państwa do pogwałcenia postanowień konwencji haskiej (według doktryny niemieckiej) w związku z wprowadzeniem na Górnym Śląsku Niemieckiej Listy Narodowościowej dojść nie mogło, ponieważ wygasła całkowicie podmiotowość państwa polskiego (tak jak gdyby nigdy ono nie istniało), a tym samym nie było konieczne stosowanie się do postanowień konwencji. Opanowane zaś terytorium i zamieszkującą je ludność stały się elementem pozostającym w sferze prawa wewnętrznego Rzeszy Niemieckiej, w której element polityczny wiódł prymat nad postanowieniami prawa.

Analizując zatem legalność ( $w$ tym zgodność z postanowieniami konwencji haskiej) decyzji o wprowadzeniu Niemieckiej Listy Narodowościowej na Górnym Śląsku należy zauważyć, iż w świetle niemieckiej wykładni prawa międzynarodowego z lat 1933-1945 nie prowadziła ona do pogwałcenia zobowiązań prawa międzynarodowego (w tym samej konwencji haskiej) oraz wpisywała się w postulowany przez nich system prawa wewnętrznego III Rzeszy.

W pierwszej kolejności należy zwrócić uwagę, że decyzja o wprowadzeniu Niemieckiej Listy Narodowościowej na terenie Górnego Śląska była decyzją czysto polityczną i już w tym sensie wpisuje się w ogólne ramy zasady wodzostwa, $\mathrm{w}$ których to polityka (w tym polityka zagraniczna) miała wieść prym nad postanowieniami i przepisami prawa. W tym kontekście sam Schmitt posunął się do próby zalegalizowania wojny napastniczej (jako formy realizacji polityki Rzeszy), o ile doprowadziłaby ona do całkowitego zajęcia terytorium wrogiego państwa nawet jeżeli nie zostało podpisane porozumienie pokojowe, władze kraju 
udały się na emigrację, a siły zbrojne wrogiego państwa prowadziły w dalszym ciągu operacje przeciwko siłom napastnika - w ramach powszechnego powstania zbrojnego (jak w przypadku Abisynii w latach 1936-1941) lub w ramach prowadzenia wojny koalicyjnej (jak w przypadku Polski w latach 1939-1945). W tym momencie terytorium okupowane stawało się sferą wyłącznego oddziaływania III Rzeszy, która pozostawać miała wolna od ingerencji sił zewnętrznych (w tym od postanowień przepisów prawa międzynarodowego) i przede wszystkim kształtować system prawny pod dyktando racji politycznych (a jak wiadomo z pierwszej części artykułu, za wprowadzeniem na terenach Górnego Śląska Niemieckiej Listy Narodowościowej przemawiały szerokie względy polityczne, w tym założenia polityki rasowej Rzeszy). Ponadto według wykładni prawa międzynarodowego zaproponowanej przez Schmitta państwo, które nie jest zdolne do samodzielnego utrzymania wystarczającego poziomu organizacji (według Schmitta utożsamianej ze zdolnością do kontrolowania chociaż fragmentu swojego terytorium) nie tylko przestaje być państwem, lecz ukazuje społeczności międzynarodowej, że nigdy nim nie było. W tym kontekście, terytorium II RP chociaż w świetle czwartej konwencji haskiej znajdowało się pod okupacją, a podmiotowość prawna państwa polskiego trwała nadal, utraciło (dla prawników niemieckich) miano podmiotu prawa międzynarodowego. To z kolei prowadzić miało do wygaśnięcia wszelkich łączących dotychczas III Rzeszę i II Rzeczpospolitą powiązań na gruncie prawa międzynarodowego. W tym kontekście decyzja o wprowadzeniu Niemieckiej Listy Narodowościowej na Górnym Śląsku nie mogła stanowić naruszenia konwencji haskiej, ponieważ przyjmując fikcję nieistniejącego nigdy państwa polskiego sama konwencja musiała zostać uznana za nigdy nieobowiązującą. Warto zwrócić również uwagę, że wykładnia zaproponowana przez Carla Schmitta stanowi swego rodzaju dostosowanie wykładni zaproponowanej przez prawników polskich (zgodnej z powszechnie obowiązującą wówczas wykładnią prawa międzynarodowego) dla potrzeb niemieckich - szczególnie na gruncie rozważań nad ustaniem podmiotowości państwa. Schmitt nie mógł powołać się na pojęcie debellatio, ponieważ w tym stanie konieczne jest pełne przyjęcie ludności zamieszkującej zawojowany obszar w poczet narodu, bez zróżnicowania ich praw i obowiązków. W przypadku Niemieckiej Listy Narodowościowej na Górnym Śląsku nie chodziło jednak o włączenie w poczet wspólnoty narodowej wszystkich zamieszkujących na nim byłych obywateli państwa polskiego, lecz jedynie tych, którzy mogli wykazać swoje niemieckie pochodzenie (w ten sam sposób postępowano również w przypadku innych, podbitych przez Wehrmacht obszarów) zatem debellatio nie stanowiło skutecznego narzędzia realizacji niemieckiej polityki narodowościowej - stąd wprowadzenie nowej wykładni, według której państwo, którego terytorium zostało całkowicie opanowane przez siły zbrojne agresora traciło swoją podmiotowość tak, jakby nigdy jej nie posiadało. W świetle tak stworzonej wykładni prawa międzynarodowego wprowadzenie Niemieckiej 
Listy Narodowościowej na Górnym Śląsku miało stać się zgodne z jego postanowieniami.

\section{Zakończenie}

$\mathrm{Na}$ podstawie porównania wykładni prawa międzynarodowego obowiązującej w III Rzeszy i Polsce (w latach 1918-1945) oraz zastosowanej przez Międzynarodowy Trybunał Karny możliwe stało się ukazanie problemu legalności wprowadzenia Niemieckiej Listy Narodowościowej na Górnym Śląsku z dwóch perspektyw. Pierwszą stanowiła wykładnia oparta na klasycznym sposobie postrzegania prawa międzynarodowego, akceptująca jego prymat nad prawem wewnętrznym. W jej świetle możliwe stało się ukazanie wielu naruszeń, których dopuściły się władze niemieckie w związku z wprowadzeniem Niemieckiej Listy Narodowościowej na Górnym Śląsku.Wynikały one nie tylko z samego działu trzeciego czwartej konwencji haskiej lecz również z wielu innych aktów prawnych, które składały się na oficjalnie akceptowany ówcześnie (nawet przez III Rzeszę) porządek prawny. Z drugiej strony, możliwe stało się również ukazanie, do jak odmiennych wniosków można dojść przy ocenie tego samego stanu faktycznego w świetle tych samych przepisów, jeżeli podporządkuje się prawo międzynarodowe prawu wewnętrznemu państwa, którego cały system prawny zostanie podporządkowany polityce. Chociaż współcześnie nikt nie kwestionuje już bezprawnego działania III Rzeszy, szczególnie w świetle prawa międzynarodowego, przedstawienie tworzonej przez jej prawników doktryny oraz wykładni obowiązujących przepisów stanowi nadal znaczący przykład, który powinien przypominać kolejnym pokoleniom akademickich prawników o odpowiedzialności, która ciąży na nich w związku z opracowywaniem kolejnych wzorców wykładni (w świetle której najbardziej bezprawne działania mogą doczekać się uznania za obowiązujące prawo, które będzie oddziaływało na sytuację objętych jego postanowieniami podmiotów).

\section{Bibliografia}

Cyprian T., Sawicki J., Walka o zasady norymberskie 1945-1955, Warszawa 1956.

Kaczmarek R., Górny Śląsk podczas II wojny światowej, Katowice 2006.

Kaczmarek R., Polacy w Wehrmachcie, Kraków 2010.

Klafkowski A., Okupacja niemiecka w Polsce w świetle prawa narodów, Poznań 1946.

Konieczny A., Pod rządami wojennego prawa karnego Trzeciej Rzeszy Górny Śląsk 1939-1945, Wrocław-Warszawa 1972.

Makowski J., Prawo międzynarodowe. Czesść I, Warszawa 1930. 
Niesyto J., Kaj jest Józek? Wspomnienia wojenne Józefa Niesyto, Chorzów 2015.

Olejnik L., Zdrajcy narodu? Losy Volksdeutschów w Polsce po II wojnie światowej, Warszawa 2006.

Pospieszalski K.M., Polska pod niemieckim prawem 1939-1945 (ziemie zachodnie), Poznań 1946.

Ryszka F., Norymberga. Prehistoria i ciag dalszy, Warszawa 1982.

Ryszka F., Państwo stanu wyjątkowego. Rzecz o systemie państwa i prawa Trzeciej Rzeszy, Wrocław-Warszawa-Kraków-Gdańsk 1974.

Schmitt C., Porządek wielkoobszarowy w prawie międzynarodowym, Warszawa 2009.

\section{Źródła internetowe}

Konwencja dotycząca praw i zwyczajów wojny lądowej (Dz.U. 1927 nr 21, poz. 161), http://isap.sejm.gov.pl/isap.nsf/download.xsp/WDU19270210161/O/ D19270161.pdf (dostęp: 06.01.2021).

Traktat Przeciwwojenny, podpisany w Paryżu dnia 27 sierpnia 1928 r. (ratyfikowany zgodnie z ustawą z dnia 13 lutego 1929 r.); (Dz.U. 1929 nr 63, poz. 489), http:// isap.sejm.gov.pl/isap.nsf/download.xsp/WDU19290630489/O/D19290489. pdf (dostęp: na 06.01.2021).

\section{STRESZCZENIE}

W artykule została przedstawiona sprawa Niemieckiej Listy Narodowościowej na Górnym Śląsku zarówno z perspektywy stosunków polsko-niemieckich jak i z perspektywy historyczno-prawnej. W pierwszej części zaprezentowana została skomplikowana sytuacja osób, które zostały nią objęte. Opisane dwie, skrajnie różne relacje pozwalają na obrazowe zarysowanie trudnego losu polskiej ludności Górnego Śląska w latach 1939-1945, wobec której stosowano różne środki przymusu w celu jej całkowitego wcielenia w niemiecką wspólnotę narodowościową. Jak zostało to ukazane w artykule, były to jednak działania czysto instrumentalne, mające na celu przede wszystkim dostarczenie nowych rekrutów dla wykrwawiającej się na frontach II wojny światowej armii oraz pozyskanie wykwalifikowanych pracowników mogących utrzymać tempo produkcji niezbędnych dla gospodarki wojennej III Rzeszy produktów (przede wszystkim węgla i stali). Czytelnik po zapoznaniu się z literalnym brzmieniem czwartej konwencji haskiej w drugiej części artykułu będzie mógł zauważyć drastyczne bezprawie, do jakiego doszło w związku z wprowadzeniem Niemieckiej Listy Narodowej na Górnym Śląsku. Dostrzegli je również prawnicy polscy, którzy szczególnie po zakończeniu II wojny światowej podjęli aktywną działalność na rzecz ukazania światu rozmiaru bezprawia, które w latach 1939-1945 objęło byłe polskie tereny Górnego Śląska. Jednak samo przedstawienie stanowiska prawników polskich nie oddaje w pełni rozmiaru tej tragedii - właśnie dlatego, zdecydowałem się na zaprezentowanie w trzeciej części artykułu interpretacji prawników niemieckich, według której wszystkie działania podjęte 
przez władze niemieckie na Górnym Śląsku w latach 1939-1945 były w pełni zgodne z przepisami prawa międzynarodowego, w tym z samą konwencją haską. Chociaż współcześnie nikt nie powątpiewa już w bezprawie aktów uchwalanych w ramach wykładni głoszącej całkowity upadek państwa polskiego już we wrześniu 1939 r., zaprezentowanie wykładni prawa międzynarodowego tak skrajnie sprzecznej z jego fundamentami umożliwia przypomnienie o odpowiedzialności, jaka ciąży na teoretykach prawa, których akademickie rozważania mogą zostać wcielone w życie i w ten sposób doprowadzić do stworzenia prawnej argumentacji na rzecz bezprawnych działań.

\section{SUMMARY}

\section{Law or Lawlessness? The Legality of Introducing the German People's List in Upper Silesia in the Light of the Fourth Hague Convention Perceived by the Interpretation of International Law by German and Polish Lawyers}

The article presents the issue of the German National List in Upper Silesia, both from the perspective of Polish-German relations and from the historical and legal perspective. The first part presents the complicated situation of people who were covered by it. The description of the two, extremely different views shows illustratively the difficult fate of the Polish population of Upper Silesia in the years 1939-1945, against whom various coercive measures were used to fully incorporate it into the German national community. As it was presented in the article, these were purely instrumental actions, aimed primarily at providing new recruits for the army bleeding out on the fronts of World War II and at recruiting qualified workers who could maintain the pace of production of products necessary for the war economy of the Third Reich (primarily coal and steel). After reading the literal wording of the Fourth Hague Convention in the second part of the article, the reader will be able to notice the drastic lawlessness that occurred after the introduction of the German National List in Upper Silesia. It was also noticed by Polish lawyers who, especially after the end of World War II, undertook many activities to show the world the extent of the lawlessness that covered the former Polish territories of Upper Silesia in the years 1939-1945. However, presenting standpoint of Polish lawyers does not fully reflect the scale of this tragedy - and this is why I decided to present, in the third part of the article, the interpretation of German lawyers, according to which all actions taken by the German authorities in Upper Silesia between 1939 and 1945 were fully compliant with international law, including the Hague Convention itself. Although nowadays no one doubts the lawlessness of acts enacted as part of the interpretation proclaiming the complete collapse of the Polish state as early as in September 1939, presenting an interpretation of international law so extremely inconsistent with its foundations makes it possible to recall the responsibility that lies on theoreticians of law, whose academic considerations may become implemented and thus lead to the creation of a legal argument in favor of unlawful actions. 